\title{
STRAIN DIFFERENCES IN THE EXPRESSION OF THE EPA-1-RESTRICTING ELEMENT
}

\author{
G. A. Hadley, ${ }^{*}$ M. E. Snider and D. Steinguller \\ Department of Surgery, University of Michigan Medical School, Ann Arbor, MI, U.S.A.
}

(Received 14 October 1986; revised version 24 February 1987)

\begin{abstract}
SUMMARY
Epa-1-specific cytotoxic T lymphocytes (CTL) lyse epidermal cells (EC) of different Epa-1+ $H-2^{*}$ strains, such as AKR, CBA, C58, and RF, at different levels. We used an $\mathrm{H}-2 \mathrm{~K}^{\mathrm{k}}$-specific monoclonal antibody $(\mathrm{mAb})$ to test the hypothesis that this phenomenon is due to differences in the $\mathrm{H}$-2-restricting element. Initially, we established the specificity of this mAb for the Epa-1restricting element by demonstrating its capacity to inhibit the lysis of CBA EC by Epa-1-specific CTL. We then used it as the probe in a cellular radioimmunoassay to quantify the expression of the restricting element by EC of different $H-2^{k}$ strains. We found that C58 and RF EC bound significantly less of the mAb than did CBA EC. Although AKR also bound less of the mAb than did CBA EC, the difference was not statistically significant. To examine the generality of this phenomenon, we quantified the expression of $\mathrm{K}^{\mathrm{k}}$ antigens on spleen cells (SC) of the same four strains. We found that RF SC, but not AKR or C58 SC, bound significantly less of the $\mathrm{K}^{\mathrm{k}} \mathrm{mAb}$ than did CBA SC. Thus, the differential CTL lysis of Epa-1+ EC of different strains probably reflects differences in expression of the H-2-restricting element rather than of the nominal antigen.
\end{abstract}

\section{INTRODUCTION}

Epa-1 is a non-H-2 alloantigen that is expressed well on epidermal cells (EC), fibroblasts and activated macrophages but is poorly expressed, if at all, on lymphocytes (Steinmuller et al., 1981a; Burlingham et al., 1983, 1984). In vivo, Epa-1 functions as a minor histocompatibility antigen in the rejection of skin allografts and in local cutaneous graft-versus-host reactions (Steinmuller et al., 1982; Tyler et al., 1984). An antigen that cross-reacts with Epa-1 is expressed on EC of rats and humans (Steinmuller \& Tyler, 1983). In genetic studies, Epa-I behaves as a single Mendelian locus (Steinmuller et al., 1981b). The Epa-1 gene does not appear to be very polymorphic: $\mathrm{C} 3 \mathrm{H} / \mathrm{An}, \mathrm{C} 3 \mathrm{H} / \mathrm{He}, \mathrm{C} 3 \mathrm{Heb} / \mathrm{Fe}, \mathrm{A} / \mathrm{He}, \mathrm{A} / \mathrm{J}, \mathrm{LG}$, and ST are Epa-1- but 43 other mouse strains are Epa-1+ (Steinmuller et al., 1985).

* Present address: Abbott Laboratories, Abbott Park, IL 60064, U.S.A.

Correspondence: Dr D. Steinmuller, Tissue Typing Laboratory, 1520 MSRB I, Box 0666, University of Michigan Medical School, Ann Arbor, MI 48109-0666, U.S.A. 
Epa-1 is defined in mice by the specificity of $I r$ gene-regulated, IL-2-dependent, cytotoxic T lymphocytes (CTL) (Steinmuller et al., 1981a; Tyler \& Steinmuller 1981, 1982; Tyler et al., 1982). Typically, Epa-1-specific CTL are raised in $\mathrm{C} 3 \mathrm{H} / \mathrm{He}$ hosts and are restricted by a gene product mapping to the $K$ region of the $H$-2 complex (Steinmuller et al., 1981a; Tyler et al., 1982). Recently Steinmuller and colleagues (1985) examined the susceptibility of EC of 25 different $\mathrm{H}-2 \mathrm{~K}^{\mathrm{k}}$. mouse strains to lysis by Epa-1-specific CTL; some of the results of their study are shown in Table 1. Note the broad range of values for EC targets from the four Epa$1^{+}$strains. Others have demonstrated a direct relationship between the level of expression of $\mathrm{H}$-2-restricting elements and the susceptibility of cells to lysis by CTL directed against nonH-2 antigens (Flores \& Gilmer, 1984; Flyer et al., 1985; Meruelo, 1979; O'Neill \& Blanden,

TABLE 1. Reactivity of Epa-1-specific cytotoxic T lymphocytes* with epidermal cells of five different $\mathrm{H}-2^{\mathrm{k}}$ strains $\dagger$

\begin{tabular}{lcccc}
\hline \multicolumn{2}{c}{ Target cells } & & \\
\cline { 1 - 2 } Strain & $\begin{array}{c}\text { Epa-1 } \\
\text { phenotype }\end{array}$ & No. $\neq$ & $\begin{array}{c}\% \text { specific lysis } \\
\text { of epidermal cells } \\
\text { mean } \pm \text { SE }\end{array}$ \\
\hline $\mathrm{CBA} / \mathrm{J}$ & + & 56 & $60.9 \pm 1.6$ \\
$\mathrm{AKR} / \mathrm{J}$ & + & 19 & $46.5 \pm 2.9$ \\
$\mathrm{C} 58 / \mathrm{J}$ & + & 4 & $44.5 \pm 3.7$ \\
$\mathrm{RF} / \mathrm{J}$ & + & 15 & $32.5 \pm 3.1$ \\
$\mathrm{C} 3 \mathrm{H} / \mathrm{HeJ}$ & - & 58 & $5.8 \pm 0.6$ \\
\hline
\end{tabular}

* Generated by priming $\mathrm{C} 3 \mathrm{H} / \mathrm{He}$ mice with CBA epidermal cells, then boosting host splenocytes by co-culturing them with irradiated CBA epidermal cells, as described in detail elsewhere (Steinmuller \& Tyler, 1980).

$\uparrow$ Data from Steinmuller et al., 1985.

$\ddagger$ Number of mice tested.

1979; Schmidt \& Festenstein, 1982). Since Epa-1-specific CTL recognize Epa-1 only in the context of H-2K ${ }^{k}$ (Steinmuller et al., 1981 a), the differences in lysis of EC from different Epa$1^{+}$strains might reflect differences in the expression of either Epa-1 or $\mathrm{H}-2 \mathrm{~K}^{\mathrm{k}}$ antigens. The first alternative is not testable because, as for non-MHC antigens in general (Loveland \& Simpson, 1986), Epa-1 does not appear to evoke a humoral response and such antibodies would be required to evaluate quantitative differences in Epa-1 expression on EC of different strains. However, the second alternative is testable because $\mathrm{H}-2 \mathrm{~K}^{\mathrm{k}}$-specific antibodies are readily available. The purpose of the present investigation was to quantify possible differences in the expression of $\mathrm{H}-2 \mathrm{~K}^{\mathrm{k}}$ by $\mathrm{EC}$ of four representative Epa-1+ ${ }^{+}$strains, $\mathrm{AKR}$, CBA, C58, and RF, that show different degrees of susceptibility to Epa-1-specific CTL.

\section{MATERIALS AND METHODS}

Mice

We purchased BALB/CByJ $\left(H-2^{d}\right), \mathrm{C} 57 \mathrm{BL} / 10(\mathrm{~B} 10)$ and $\mathrm{C} 3 \mathrm{H}$.SW (both $\left.H-2^{b}\right)$ and AKR/J, BIO.BR/SgSnJ, CBA/J, C3H/HeJ, C58/J and RF/J (all $H-2^{k}$ ) mice from the Jackson Laboratory, Bar Harbor, ME, and bred $\mathrm{F}_{1}$ hybrid mice locally. B10.A(4R) mice $\left(H-2^{k} I^{k} D^{b}\right)$ 
were kindly provided by Dr John Niederhuber of the University of Michigan, Ann Arbor, MI. We used adult mice of both sexes as hosts in immunizations but selected the sex of the donor so as to preclude the induction of responses to the H-Y antigen (Wachtel, 1977).

\section{Cell preparations and cell-mediated cytotoxicity (CMC) assays}

We prepared mouse EC by trypsinization of tail and ear skin as described elsewhere (Steinmuller \& Tyler, 1980). Briefly, we floated skin dermis-down on a solution of $0.5 \%(\mathrm{w} / \mathrm{v})$ trypsin (Gibco, Grand Island, NY, U.S.A.; no. 610-5095) in phosphate-buffered saline (PBS) minus calcium and magnesium for $70-90 \mathrm{~min}$ at $37^{\circ} \mathrm{C}$ in a $5 \% \mathrm{CO}_{2}$ humidified incubator. We then separated the dermis and epidermis using fine forceps and rubbed the EC off the exposed surfaces with small glass probes into a solution of $0.025 \%(\mathrm{w} / \mathrm{v})$ DNase (Sigma, St Louis, MO, U.S.A.; no. D-0876) and 10\% (v/v) fetal calf serum (FCS) in MishelDutton phosphate-buffered balanced salt solution (BSS). We filtered the resulting suspensions through $110 \mu$ porosity nylon mesh (Tetko Inc., Elmsford, NY, U.S.A.) and centrifuged it at $300 \mathrm{~g}$ to pellet the EC. We used EC suspensions at this point as immunogens for in vivo and in vitro immunizations. We further purified $\mathrm{EC}$ and $\mathrm{SC}$ to be used as targets in the cellular radioimmunoassay (cRIA) by centrifugation over a Ficoll-Hypaque gradient (density 1.077) at $300 \mathrm{~g}$ for $15 \mathrm{~min}$ to remove non-viable and clumped cells. We filtered the EC used as targets in cell-mediated cytotoxicity (CMC) assays through a small amount of thoroughly washed glass-wool packed in a syringe barrel (Steinmuller \& Tyler, 1980). We obtained mouse SC by teasing spleens in BSS containing $10 \%(\mathrm{v} / \mathrm{v}) \mathrm{FCS}$ and filtering through the nylon mesh mentioned above. Our methods of generating Epa-1-specific CTL and assaying them in direct and cold-target inhibition 3-h chromium-release CMC assays are presented in detail elsewhere (Steinmuller \& Tyler, 1980; Steinmuller et al., 1981a; Tyler \& Steinmuller, 1981).

\section{Monoclonal antibodies ( $m A b s$ )}

We obtained hybridomas 16-1-11N (ATCC no. HB-16) and 15-5-5S (ATCC no. HB-24) from The American Type Culture Collection, Rockville, MD, U.S.A. The antibodies secreted by these hybridomas are specific for $\mathrm{H}-2 \mathrm{~K}^{\mathrm{k}}$ and $\mathrm{H}-2 \mathrm{D}^{\mathrm{k}}$ antigens, respectively (Ozato et al., 1980). For the production of ascitic fluid, we passaged the hybridomas in histocompatible $(\mathrm{C} 3 \mathrm{H} . \mathrm{SW} \times \mathrm{BALB} / \mathrm{c}) \mathrm{F}_{1}$ hybrid hosts and collected the fluid from the resulting ascites. We then centrifuged the ascitic fluid in a microfuge (Beckman, Fullerton, CA, U.S.A.; model B) for $1 \mathrm{~min}$ at 7,000 $\mathrm{g}$ to remove cells and debris. For the production of hybridoma culture supernatants, we grew the hybridomas to maximum cell density in culture and harvested the medium by passage through a filter with $0.2 \mu$ porosity (Nalgene, Rochester, NY, U.S.A.; no. 120-0020). We aliquoted and stored the culture supernatant and ascitic fluid at $-70^{\circ} \mathrm{C}$ until use. Immediately prior to use, we heat-inactivated aliquots of ascitic fluid by incubation in a $56^{\circ} \mathrm{C}$ water bath for $30 \mathrm{~min}$.

\section{CTL-blocking assays}

We performed these assays as described by Epstein and co-workers (1980), with a slight modification. Briefly, we added $5 \times 10^{4}$ target cells in 20-100 $\mu \mathrm{l}$ aliquots of blocking antibody diluted in MEM containing 10\% FCS and $25 \mathrm{mM}$ HEPES buffer (MEM + ) and incubated the trays for $30 \mathrm{~min}$ at $4^{\circ} \mathrm{C}$. We then added effector cells to a volume of $100 \mu \mathrm{l}$. Otherwise, we performed these assays as described above for the $\mathrm{CMC}$ assays. 


\section{Cellular radioimmunoassay $(c R I A)$}

We used a modification of a cRIA developed by Pierres and associates (1980). Briefly, we added $2.5 \times 10^{5}$ target cells to four 200- $\mu$ l aliquots of antibody in MEM + to wells of conicalbottomed microtitre trays. After incubation for $90 \mathrm{~min}$ at $4^{\circ} \mathrm{C}$, we washed the wells three times by centrifugation for $8 \mathrm{~min}$ at $300 \mathrm{~g}$, flicking out the supernatant, and resuspending the cells in $150 \mu \mathrm{l}$ of PBS containing $0.2 \%(\mathrm{w} / \mathrm{v})$ sodium azide and $0.2 \%(\mathrm{w} / \mathrm{v})$ bovine serum albumin (BSA). We then added $1 \times 10^{5}$ counts per minute (cpm) of ${ }^{125}$ I-labelled staphylococcal protein A (Amersham, Arlington Heights, IL, U.S.A.; no. IM.112) in $50 \mu \mathrm{l}$ of PBS to each well. After incubation for $30 \mathrm{~min}$ at $4^{\circ} \mathrm{C}$, we washed the wells four times and harvested their contents on to filter-paper discs using a cell harvester. We measured the radioactivity bound to the discs with a gamma counter (Beckman, Fullerton, CA, U.S.A.; Model 5500). We then calculated the mean of the replicates for each antibody sample after subtracting the average machine background cpm obtained by measuring the radioactivity registered by at least four blank counting tubes.

\section{RESULTS}

In order to evaluate whether or not EC of the AKR, C58, and RF mouse strains express reduced levels of the $\mathrm{K}^{\mathrm{k}}$-restricting element for Epa-1-specific CTL compared to CBA EC, we required a reagent that specifically recognizes the restricting element. For this purpose, we obtained hybridoma 16-1-11N which secretes a well-characterized $\mathrm{mAb}$ which binds to $\mathrm{H}-2 \mathrm{~K}^{\mathrm{k}}$ and does not cross-react with other $\mathrm{H}-2^{k}$ gene products (Ozato et al., 1980; see Materials and Methods). However, the $\mathrm{H}-2 \mathrm{~K}^{\mathrm{k}}$ reactivity of this $\mathrm{mAb}$ does not guarantee its specificity for the antigen-restricting Epa-1-specific CTL because recent studies have shown that the $K$ region of the $H-2$ complex encodes at least two distinct class I antigens, though only

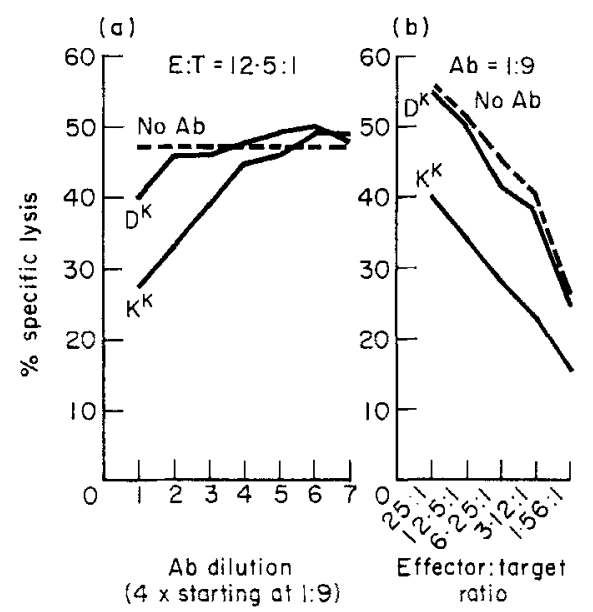

FIG. 1. Results of cytotoxic T-lymphocyte (CTL) blocking studies. Monoclonal antibodies (mAbs) with specificity for $\mathrm{H}-2 \mathrm{~K}^{\mathrm{k}}\left(\mathrm{K}^{\mathrm{k}}\right)$ and $\mathrm{H}-2 \mathrm{D}^{\mathrm{k}}\left(\mathrm{D}^{\mathrm{k}}\right)$ antigens were assayed for the capacity to inhibit the lysis of Epa-1+ CBA epidermal cells by Epa-1-specific CTL. (a) The effector to target cell ratio (E:T) was held constant at $12 \cdot 5: 1$ and the antibody dilution was varied. (b) The antibody dilution was held constant at $1: 9$ and the $E: T$ was varied. The broken line represents the level of target cell lysis in the absence of antibody. 
one is expressed in all strains examined so far (Tryphonas et al., 1983; Weiss et al., 1984). Therefore, in the initial step of this project we tested the $\mathrm{H}-2 \mathrm{~K}^{\mathrm{k}}$-specific $\mathrm{mAb}$ in CTLblocking studies to establish its specificity for the Epa-1-restricting element and thus determine whether it could be used to quantify the expression of the element by $\mathrm{EC}$ of different mouse strains.

Figure la shows the results of an experiment in which the anti-H-2K${ }^{\mathrm{k}} \mathrm{mAb}$ and an anti-H$2 \mathrm{D}^{\mathrm{k}}$ control mAb were tested for their capacity to block the lysis of Epa-1+ EC by Epa-1specific CTL. Note the strong inhibition produced by the anti-K $\mathrm{K}^{\mathrm{k}} \mathrm{mAb}$ compared to that by the anti- $\mathrm{D}^{\mathrm{k}} \mathrm{mAb}$. We repeated this experiment on five separate occasions and obtained a similar degree of inhibition each time. In this particular experiment, the anti- $\mathrm{D}^{\mathrm{k}} \mathrm{mAb}$ caused some inhibition at the lowest antibody dilution, but this was not a consistent finding. Figure $1 \mathrm{~b}$ shows that the anti- $\mathrm{K}^{\mathrm{k}}$ antibody specifically inhibits target cell lysis over a broad range of effector to target $(\mathrm{E}: \mathrm{T})$ ratios. Thus, the anti- $\mathrm{K}^{\mathrm{k}} \mathrm{mAb}$ clearly reacts with the gene product that restricts Epa-1-specific CTL.

Previous studies have established the reliability of cRIAs in the quantification of molecules on the cell surface (Ada \& Yap, 1979; Gerlier \& Avice, 1984; O'Neill, 1984; O'Neill \& Blanden, 1979). Therefore, we used the anti-K ${ }^{k} \mathrm{mAb}$ as a probe in a cRIA to compare the expression of the Epa-1-restricting element by AKR, CBA, C58, and RF EC. We included $\mathrm{H}-2^{\mathrm{d}} \mathrm{BALB} / \mathrm{c} \mathrm{EC}$ to control for non-specific binding, and a sample composed of $80 \% \mathrm{CBA}$ EC and $20 \% \mathrm{BALB} / \mathrm{c}$ EC as an internal standard; the latter cell mixture should

TABLE 2. Reactivity of $\mathrm{H}-2 \mathrm{~K}^{\mathrm{k}}$-specific monoclonal antibody with epidermal cells (EC) of four $\mathrm{H}-2^{\mathrm{k}}$ strains in the cellular RIA

\begin{tabular}{|c|c|c|c|c|c|c|}
\hline \multirow{2}{*}{$\begin{array}{l}\text { Antibody } \\
\text { dilution* }\end{array}$} & \multicolumn{6}{|c|}{ Radioactivity bound (cpm) $\dagger$} \\
\hline & CBA & RF & C58 & AKR & $80 \% \mathrm{CBA} \ddagger$ & $\mathrm{BALB} / \mathrm{c}$ \\
\hline 1 & $\begin{array}{c}1956 \pm 94 \\
(1943)\end{array}$ & $\begin{array}{c}1452 \pm 99 \\
(1605)\end{array}$ & $\begin{array}{c}1572 \pm 48 \\
(1448)\end{array}$ & $\begin{array}{c}1756 \pm 133 \\
\quad(1703)\end{array}$ & $\begin{array}{c}1715 \pm 139 \\
(1649)\end{array}$ & $\begin{array}{c}814 \pm 78 \\
\quad(922)\end{array}$ \\
\hline 2 & $\begin{array}{c}1796 \pm 87 \\
(1775)\end{array}$ & $\begin{array}{c}1274 \pm 100 \\
\quad(1462)\end{array}$ & $\begin{array}{c}1402 \pm 33 \\
(1292)\end{array}$ & $\begin{array}{c}1650 \pm 143 \\
\quad(1615)\end{array}$ & $\begin{array}{c}1574 \pm 102 \\
\quad(1514)\end{array}$ & $\begin{array}{c}692 \pm 47 \\
(731)\end{array}$ \\
\hline 3 & $\begin{array}{c}1694 \pm 95 \\
(1671)\end{array}$ & $\begin{array}{c}1202 \pm 109 \\
\quad(1412)\end{array}$ & $\begin{array}{c}1434 \pm 37 \\
(1311)\end{array}$ & $\begin{array}{c}1555 \pm 116 \\
(1515)\end{array}$ & $\begin{array}{c}1554 \pm 85 \\
(1488)\end{array}$ & $\begin{array}{c}666 \pm 57 \\
(710)\end{array}$ \\
\hline 4 & $\begin{array}{c}1634 \pm 91 \\
(1612)\end{array}$ & $\begin{array}{c}1148 \pm 102 \\
(1344)\end{array}$ & $\begin{array}{c}1359 \pm 32 \\
(1243)\end{array}$ & $\begin{array}{c}1494 \pm 117 \\
\quad(1456)\end{array}$ & $\begin{array}{c}1462 \pm 93 \\
(1400)\end{array}$ & $\begin{array}{c}632 \pm 50 \\
(672)\end{array}$ \\
\hline 5 & $\begin{array}{l}1570 \pm 103 \\
(1547)\end{array}$ & $\begin{array}{c}1120 \pm 76 \\
(1328)\end{array}$ & $\begin{array}{c}1329 \pm 48 \\
(1207)\end{array}$ & $\begin{array}{l}1422 \pm 112 \\
\quad(1306)\end{array}$ & $\begin{array}{c}1418 \pm 111 \\
\quad(1352)\end{array}$ & $\begin{array}{c}650 \pm 43 \\
(693)\end{array}$ \\
\hline 6 & $\begin{array}{l}1081 \pm 84 \\
\quad(1065)\end{array}$ & $\begin{array}{c}851 \pm 51 \\
(996)\end{array}$ & $\begin{array}{c}996 \pm 32 \\
(911)\end{array}$ & $\begin{array}{c}1051 \pm 79 \\
(1023)\end{array}$ & $\begin{array}{c}1065 \pm 85 \\
(1019)\end{array}$ & $\begin{array}{c}644 \pm 45 \\
(674)\end{array}$ \\
\hline 7 & $\begin{array}{c}844 \pm 56 \\
(828)\end{array}$ & $\begin{array}{c}649 \pm 23 \\
(798)\end{array}$ & $\begin{array}{c}829 \pm 56 \\
(741)\end{array}$ & $\begin{array}{c}836 \pm 87 \\
(807)\end{array}$ & $\begin{array}{c}842 \pm 64 \\
(795)\end{array}$ & $\begin{array}{c}658 \pm 56 \\
(689)\end{array}$ \\
\hline $\begin{array}{l}\text { Reagent } \\
\text { control§ }\end{array}$ & $646 \pm 52$ & $494 \pm 12$ & $712 \pm 49$ & $662 \pm 59$ & $672 \pm 44$ & $599 \pm 45$ \\
\hline
\end{tabular}

* Five-fold dilutions of $16-1-11 \mathrm{~N}$ ascitic fluid starting at a dilution of $1: 100$.

$\dagger \mathrm{EC}$ from the five strains were tested concurrently at the seven different antibody dilutions. Values are means $\pm \mathrm{SE}$ of six experiments with adjusted means below in parentheses (see text).

$\ddagger$ This sample was an internal standard composed of $80 \% \mathrm{CBA}$ EC and $20 \% \mathrm{BALB} / \mathrm{c} \mathrm{EC}$.

$\S$ Target cells were incubated with medium alone instead of with diluted antibody but otherwise were treated the same as the experimental groups. 


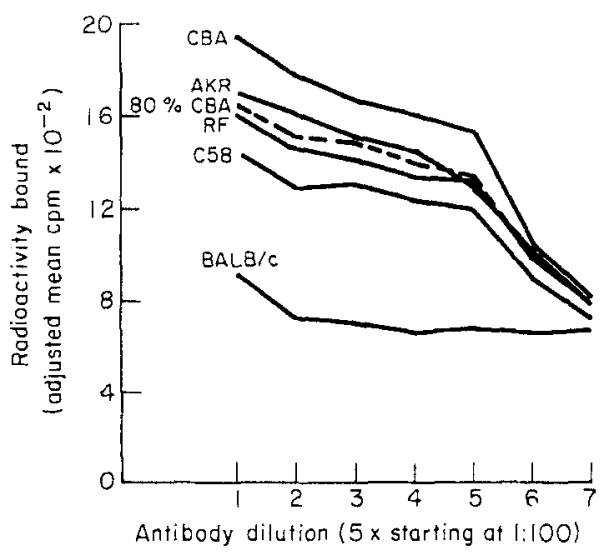

Fig. 2. Graphical presentation of the adjusted data from Table 2.

have expressed $20 \%$ fewer restricting molecules than $100 \%$ CBA EC. We tested all six EC samples concurrently at seven different antibody dilutions and repeated the assay six times.

The results from these experiments are presented in Table 2 in the form of both 'unadjusted' (raw) and 'adjusted' mean values. The rationale for adjusting the values is revealed by an inspection of the bottom row of the table. The number of counts bound in the absence of antibody (the reagent control) was different for EC of different strains. Clearly, this binding was non-specific and influenced the total binding observed in the presence of antibody. Thus, the purpose of adjusting the total binding values was to put the six strains on an equal footing with respect to this uncontrolled variable. To accomplish this, the reagent control was treated as the covariate in a randomized block analysis of covariance (Snedecor \& Cochran, 1980) and adjusted means were obtained for total binding at the various antibody dilutions.

It is apparent from Fig. 2 that the mean binding values of $A K R, R F$, and C58 EC were lower than those of CBA EC at all antibody dilutions. In fact, an analysis of covariance revealed significant differences $(P<0.001)$ among the strains at each dilution. Pair-wise comparisons of these data using Dunnett's procedure (Dunnett, 1955) revealed that the

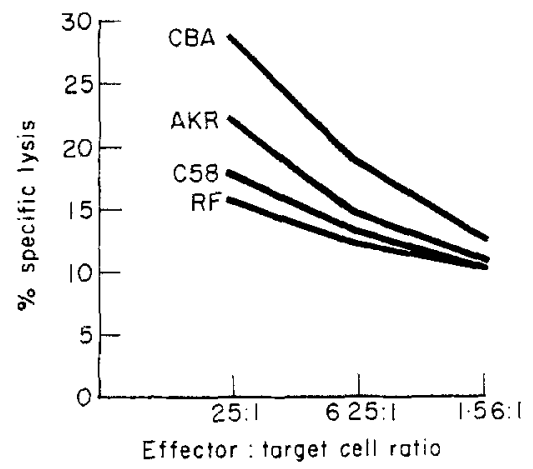

FIG. 3. Reactivity of $H-2 K^{k}$-specific cytotoxic $T$ lymphocytes with $E C$ of strains $C B A, A K R$, $\mathrm{C} 58$, and $\mathrm{RF}$ (all $\left.\mathrm{H}-2 \mathrm{~K}^{\mathrm{k}}\right)$. Effector cells were raised in $\mathrm{C} 57 \mathrm{BL} / 10\left(H-2^{b}\right)$ hosts immunized with spleen cells from the $H-2$ congenic strain $\mathrm{B} 10 . \mathrm{A}(4 \mathrm{R})\left(H-2 K^{k} I^{k} D^{b}\right)$. Values are means of seven assays. 
TABLE 3. Reactivity of Epa-1-specific cytotoxic T lymphocytes generated by immunizing $\mathrm{C} 3 \mathrm{H} / \mathrm{He}$ mice with $\mathrm{RF}$ or $\mathrm{C} 58$ epidermal cells

\begin{tabular}{ccc}
\hline $\begin{array}{c}\text { Immunizing } \\
\text { cell } \\
\text { strain }\end{array}$ & $\begin{array}{c}\text { Target } \\
\text { cell } \\
\text { strain }\end{array}$ & $\begin{array}{c}\text { Mean \% specific lysis } \\
\pm \text { SE at E:T }=25: 1 \\
\text { (four tests) }\end{array}$ \\
\hline \multirow{2}{*}{ RF } & $\mathrm{C} 3 \mathrm{H} / \mathrm{He}$ & $1 \cdot 1 \pm 1 \cdot 1$ \\
& $\mathrm{RF}$ & $28 \cdot 5 \pm 4 \cdot 2$ \\
& $\mathrm{AKR}$ & $43 \cdot 0 \pm 2 \cdot 9$ \\
& $\mathrm{CBA}$ & $54 \cdot 9 \pm 3 \cdot 1^{*}$ \\
$\mathrm{C} 58$ & $\mathrm{C} 58$ & $49 \cdot 3 \pm 8 \cdot 0$ \\
& $\mathrm{CBA}$ & $66 \cdot 0 \pm 5 \cdot 9 \dagger$ \\
\hline
\end{tabular}

$* P<0.01$ vs. RF

$\dagger 0.05>P>0.25$ us. C58.

values for C58 and RF EC were significantly different $(P<0.05)$ from the values for CBA EC at dilutions $1-5$. Thus, C58 and RF EC clearly express fewer $\mathrm{K}^{\mathrm{k}}$-restricting molecules than do CBA EC. Whether AKR EC actually express fewer restricting molecules than CBA $\mathrm{EC}$ is less clear because the difference between their mean values was significant only at dilution 5 .

As an additional approach to evaluate the relative level of $\mathrm{K}^{\mathrm{k}}$ expression by $\mathrm{EC}$ of the four strains, we assayed their susceptibility to lysis by $\mathrm{H}-2 \mathrm{~K}^{\mathrm{k}}$-specific CTL. As seen in Fig. 3, the mean per cent specific lysis values of AKR, C58 and RF EC were lower than those of CBA $E C$ at all $E: T$ ratios. An analysis of variance of these data showed that the differences between RF and CBA, and between C58 and CBA, were statistically significant $(P<0.05)$ at the highest $\mathrm{E}: \mathrm{T}$ ratio. Thus, these data corroborate the findings obtained using the cRIA.

Previously, we found that CTL populations generated by immunizing $\mathrm{C} 3 \mathrm{H} / \mathrm{He}$ mice with $\mathrm{EC}$ of any of several other $\mathrm{H}-2^{\mathrm{k}}$ strains are directed predominantly against Epa-1, with only minor reactions against other non- $\mathrm{H}-2$ antigens (Steinmuller et al., 1981a; Tyler and Steinmuller, 1981). However, to test for possible quantitative differences among Epa-1 antigens of different Epa- $1^{+}$strains, we immunized $\mathrm{C} 3 \mathrm{H} / \mathrm{He}$ hosts with $\mathrm{C} 58$ or RF EC, the EC least susceptible to lysis by Epa-1-specific CTL, and assayed the CTL so generated with those EC targets, as well as with CBA EC, most susceptible to Epa-1-specific CTL. Indeed, the CTL generated with C58 and RF immunogens still lysed CBA EC targets at higher levels (Table 3). Moreover, in cold-target inhibition assays, CBA EC always were the best inhibitors of Epa-1-specific CTL, and RF always the worst (data not shown).

Finally, to determine whether the strain differences in $\mathrm{K}^{\mathrm{k}}$ expression by $\mathrm{EC}$ also held for lymphoid cells, we assayed SC from the same five strains exactly as described above for the EC quantification experiments with the exception that $\mathrm{SC}$ were substituted as targets. The average results of six such tests are presented in Fig. 4 . These data were also subjected to a randomized block analysis of covariance. In this case, the analysis showed that the reagent control values were not significantly related to total binding in the presence of antibody. Hence, the reagent control values were excluded from the analysis and a randomized block analysis of variance was run at each antibody dilution. Figure 4 shows that the mean binding values of RF SC were clearly lower than those of the other three strains at each dilution. Pairwise comparisons of these data using Dunnett's procedure confirmed that the values for RF 


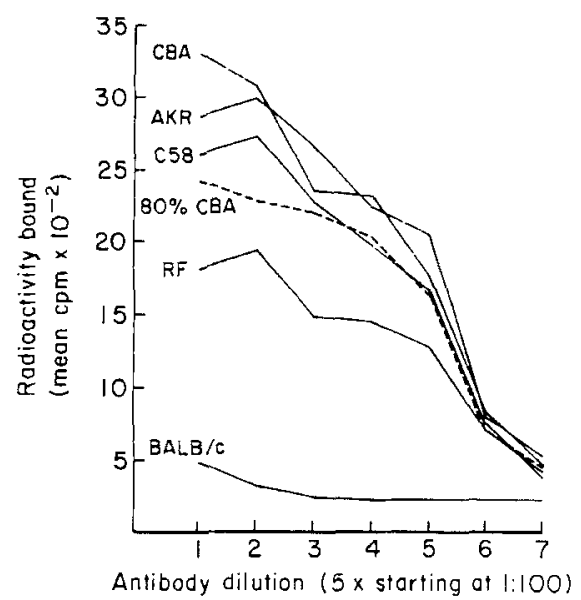

FIG. 4. Reactivity of $\mathrm{H}-2 \mathrm{~K}^{\mathrm{k}}$-specific monoclonal antibody with spleen cells (SC) of four $H-2^{k}$ strains in the cellular RIA. SC from the five strains and an internal standard (a mixture of $80 \%$ CBA SC and $20 \%$ BALB/c SC) were tested concurrently at the seven different antibody dilutions. Values are means of six assays.

SC were significantly lower $(P<0.05)$ than those of CBA SC at dilutions $1-5$. Conversely, the values for AKR and C58 SC were not significantly lower $(P<0.05)$ than those of the CBA SC at any of the dilutions.

\section{DISCUSSION}

$T$ cells recognize foreign antigen only in the context of self molecules encoded within the MHC-a phenomenon referred to as MHC restriction (Katz et al., 1973; Rosenthal \& Shevach, 1973; Zinkernagel \& Doherty, 1979). We have demonstrated the capacity of H$2 \mathrm{~K}^{\mathrm{k}}$-reactive antibodies to block the lysis of Epa-1+ EC by Epa-1-specific CTL. These results are consistent with the well known capacity of $\mathrm{H}$-2-reactive antibodies to block the lysis of target cells by CTL directed against non-H-2 alloantigens (Fischer Lindahl \& Lemke, 1979; Koo et al., 1979). Our findings are also consistent with those of Steinmuller and colleagues (1981a) who had previously mapped the restricting element for Epa-1-specific CTL to the $K$ region of the $H-2$ complex. We found that the $\mathrm{H}-2 \mathrm{~K}^{\mathrm{k}}$-specific mAb 16-1-11N caused a marked inhibition of target cell lysis over a broad range of $E: T$ ratios. This inhibition was specific because the $\mathrm{H}-2 \mathrm{D}^{\mathrm{k}}$-specific mAb 15-5-5S, which also binds to the target cells, failed to cause inhibition except at the highest antibody concentration. Thus, it seems clear that 161-11N does, in fact, recognize the H-2-restricting element for Epa-1-specific CTL.

At the highest antibody concentration used, 16-1-11N inhibited target cell lysis to $40 \%$ of that of the negative control value. We had expected to observe somewhat greater inhibition because Epstein and colleagues (1980) had reported that 16-1-11N completely blocks the lysis of target cells by $\mathrm{H}-2 \mathrm{~K}^{\mathrm{k}}$-specific CTL. However, the Epa-1-specific CTL used in our studies were raised in $\mathrm{C} 3 \mathrm{H} / \mathrm{He}$ mice and, as such, also expressed $\mathrm{H}-2 \mathrm{~K}^{\mathrm{k}}$ antigens. Thus, competitive absorption by $\mathrm{K}^{\mathrm{k}}$ antigens present on the effector cells may have accounted for the less than complete inhibition by 16-1-11N in our studies. Indeed, Epstein and colleagues (1980) have shown that competitive absorption of an antibody by effector cells can completely eliminate its capacity to inhibit target cell lysis by CTL. The aforementioned inability of the H-2D $\mathrm{D}_{-}$ specific control $\mathrm{mAb}$ to inhibit target cell lysis indicates that the binding of antibody to the effector cells per se has little effect on their lytic activity. 
We utilized mAb 16-1-11N as the probe in a cRIA to demonstrate differential levels of $\mathrm{H}$ $2 \mathrm{~K}^{\mathrm{k}}$ expression by EC of different $H-2^{k}$ strains. These differences correlated closely with the susceptibility of the strains to lysis by Epa-1-specific CTL. Thus, the simplest explanation for the differential susceptibility of EC of different strains to lysis by Epa-1-specific CTL lies in the differential expression of the $\mathrm{H}$-2-restricting element. These findings are consistent with the results of earlier studies that have shown that recognition of the H-2-restricting elementrather than recognition of the target antigen itself - is the major limiting factor in the lysis of target cells by H-2-restricted CTL (Flores \& Gilmer, 1984; Flyer et al., 1985; Meruelo, 1979; O'Neill \& Blanden, 1979; Schmidt \& Festenstein, 1982).

Our findings do not rule out the possibility that differences in Epa-1 gene expression might also influence the susceptibility of the strains to lysis by Epa-1-specific CTL. In principle, such differences in Epa-1 gene expression could be quantitative or qualitative. Unfortunately, it is probably impossible to test for quantitative differences in Epa-1 gene expression without anti-Epa-1 antibody. However, if qualitative differences at the Epa- 1 locus do exist between mouse strains, they are, at best, extremely limited because, regardless of the strain origin of the EC immunogens against which they are raised, Epa-1-specific CTL consistently show the same strain reactivity pattern: CBA $>$ AKR $>$ C58 $>$ RF (Table 3 and Steinmuller et al., 1981a). Thus the same Epa-1 antigens are apparently expressed by $\mathrm{EC}$ of these strains. However, the interpretation of these data is complicated by the fact that CBA mice express higher levels of the $\mathrm{H}$-2-restricting element than do $\mathrm{EC}$ of the other strains. Hence, the dominating influence of this factor on the lytic activity of Epa-1-specific CTL would have obscured the detection of any subtle Epa-1 polymorphisms.

\section{ACKNOWLEDGMENTS}

This work was supported by U. S. Public Health Service Grants A121208 and AI23653. We are grateful to Dr David Carlin for help with the statistical analysis and to Ms Marjorie $\mathrm{M}$. Fisher for help in preparing the manuscript.

\section{REFERENCES}

ADA, G.L. \& YAP, K.L. (1979) The measurement of haemagglutinin and matrix protein present on the surface of influenza virus infected P815 mastocytoma cells. Journal of General Virology, 47, 541.

Burlingham, W.J., SNider, M.E., TYLeR, J.D. \& STeinmuller, D. (1984) Lysis of mouse macrophages, fibroblasts and epidermal cells by epidermal alloantigen-specific cytotoxic $T$ lymphocytes: effect of culture and inflammatory agents on Epa-1 expression. Cellular Immunology, 87, 553.

Burlingham, W.J., TYLer, J.D. \& Steinmuller, D. (1983) Cytotoxic T cells specific for epidermal alloantigen, Epa-1, lyse allogeneic fibroblasts and macrophages in addition to epidermal cells. Transplantation Proceedings, 15, 292.

DUNNETT, C.W. (1955) A multiple comparison procedure for comparing several treatments with a control. Journal of American Statistics Association, 50, 1096.

Epstein, S.L., OzATA, K. \& SACHS, D.H. (1980) Blocking of allogeneic cell-mediated lympholysis by monoclonal antibodies directed to H-2 antigens. Journal of Immunology, 125, 129.

FISCHER LINDAHL, K. \& LEMKE, H. (1979) Inhibition of killer-target cell interaction by monoclonal anti-H-2 antibodies. European Journal of Immunology, 9, 526.

FLORES, R.V. \& GLLMER, P.J. (1984) Differential recognition and lysis of EL4 target cells by cytotoxic T cells: differences in $\mathrm{H}-2 \mathrm{~K}^{\mathrm{b}}$ antigenic density and cytoskeletal proteins. Journal of Immunology, 132, 2767.

FLYER, D.C., BURAKOFF, S.J. \& FALLER, D.V. (1985) Retrovirus-induced changes in major histocompatibility complex antigen expression influence susceptibility to lysis by cytotoxic T lymphocytes. Journal of Immunology, 135, 2287.

GeRLIER, D. \& AVICE, T. (1984) Use of an automated cell harvester in a cellular radioimmunoassay. Journal of Immunological Methods, 75, 159. 
KaTZ, D.H., HamaOXa, T. \& BenaCerraf, B. (1973) Cell interactions between histoincompatible T and B lymphocytes. II. Failure of physiologic cooperative interactions between $\mathrm{T}$ and $\mathrm{B}$ lymphocytes from allogeneic donor strains in the humoral response to hapten-protein conjugates. Journal of Experimental Medicine, 137, 1405.

Koo, G.C., Goldrerg, C.L. \& Shen, F.W. (1979) Inhibition of H-Y cell-mediated cytolysis by H-2D antiserum. Journal of Experimental Medicine, 150, 1028.

Loveland, B. \& Simpson, E. (1986) The non-MHC transplantation antigens: neither weak nor minor. Immunology Today, 7, 223.

Meruelo, D. (1979) A role for elevated H-2 antigen expression in resistance to neoplasia caused by radiationinduced leukemia virus. Journal of Experimental Medicine, 149, 898.

O'NeILL, H.C. (1984) Heterogeneity amongst $\mathrm{H}-2 \mathrm{~K}^{\mathrm{k}}$ antigens: differential expression on lymphoid cells. Transplantation, 38, 182.

O'NEILL, H.C. \& BLANDEN, R.V. (1979) Variation in H-2 antigen expression in $\mathrm{F}_{1}$ hybrid mice: analysis using monoclonal antibodies. Australian Journal of Experimental Biology and Medical Science, 57, 627.

OzATO, K., MAYER, N. \& SACHS, D.H. (1980) Hybridoma cell lines secreting monoclonal antibodies to mouse H-2 and Ia antigens. Journal of Immunology, 124, 533.

Pierres, M., Kourilsky, F.M., Rebouah, J.P., Dosseto, M. \& Calllol, D. (1980) Distinct epitopes on $I^{k}$ gene products identified by monoclonal antibodies. European Journal of Immunology, 10, 950.

RosENTHAL, A.S. \& SHEVACH, E.M. (1973) Function of macrophages in antigen recognition by guinea pig T lymphocytes. Journal of Experimental Medicine, 138, 1194.

SCHMIDT, W. \& FESTENSTEIN, H. (1982) Resistance to cell-mediated cytotoxicity is correlated with reduction of $\mathrm{H}-2 \mathrm{~K}$ gene products in AKR leukemia. Immunogenetics, 16, 257.

SNedeCOR, G.W. \& Cochran, W.G. (1980) Statistical Methods, 7th edn, p. 365. The Iowa State University Press, Ames.

STEINMULLER, D. \& TYler, J.D. (1980) Evidence of skin-specific alloantigens in cell mediated cytotoxicity reactions. Transplantation Proceedings 12, Suppl. 1, 107.

Steinmuller, D. \& TyleR, J.D. (1983) Cross-priming reveals similar tissue-restricted CTL-defined alloantigens on mouse, rat and human epidermal cells. Transplantation Proceedings, 15, 238.

STEINMULLER, D., TYLER, J.D. \& DAVID, C.S. (1981a) Cell-mediated cytotoxicity to non-MHC alloantigens on mouse epidermal cells. I. H-2 restricted reactions among strains sharing the $H-2^{k}$ haplotype. Journal of Immunology, 126, 1747.

SteinMuller, D., TYLER, J.D. \& DAVID, C.S. (1981b) Cell-mediated cytotoxicity to non-MHC alloantigens on mouse epidermal cells. II. Genetic basis of the response of C3H mice. Journal of Immunology, 126, 1754.

Steinmuller, D., Tyler, J.D., Waddick, K.G. \& Burlingham, W.J. (1982) Epidermal alloantigen and the survival of mouse skin allografts. Transplantation, 33, 308.

Steinmuller, D., TYLeR, J.D. \& ZinSMEISTER, A.R. (1985) Strain distribution of the new tissue-restricted alloantigen Epa-1. Transplantation Proceedings, 17, 749.

TRYPHONAS, M., KING, D.P. \& JONES, P.P. (1983) Identification of a second class I antigen controlled by the $K$ end of the $H-2$ complex and its selective cellular expression. Proceedings of the National Academy of Sciences, U.S.A., 80, 1445.

Tyler, J.D., Burlingham, W.J., David, C.S. \& Sternmuller, D. (1982) Cell-mediated cytotoxicity to nonMHC alloantigens on mouse epidermal cells. VI. Influence of the MHC on the tissue-specificity of cytotoxic T lymphocyte responses. Immunogenetics, 16, 23.

Tyler, J.D., Galli, S.J., SNIDER, M.E., DvoraK, A.M. \& Steinmuller, D. (1984) Cloned Lyt-2+ cytolytic T lymphocytes destroy allogeneic tissue in vivo. Journal of Experimental Medicine, 159, 234.

TYler, J.D. \& SteinmulleR, D. (1981) Cell-mediated cytotoxicity to non-MHC alloantigens on mouse epidermal cells. III. Epidermal cell-specific cytotoxic T lymphocytes. Journal of Immunology, 126, 1759.

TYLeR, J.D. \& Steinmuller, D. (1982) Establishment of cytotoxic T lymphocyte clones to epidermal alloantigen Epa-1. Transplantation, 34, 140.

WACHTEL, S.S. (1977) H-Y antigen: genetics and serology. Immunological Reviews, 33, 33.

Weiss, E.H., Golden, L., Fahrner, K., Mellor, A., Devlin, J.J., Bullman, H., Tideens, H., Bud, H. \& FLAVELL, R.A. (1984) Organization of class I genes in the major histocompatibility complex of the C57BL/10 mouse. Nature, 310,650 .

ZINKERNAGeL, R.M. \& DOHERTY, P.C. (1979) MHC-restricted T cells: studies on the biological role of polymorphic major transplantation antigens determining $\mathrm{T}$-cell restriction specificity, function, and responsiveness. Advances in Immunology, 27, 51. 